University of Nebraska - Lincoln

DigitalCommons@University of Nebraska - Lincoln

USDA National Wildlife Research Center - Staff Publications
U.S. Department of Agriculture: Animal and Plant Health Inspection Service

January 1989

\title{
Biochemical and Morphological Characteristics in Maturing Achenes from Purple-Hulled and Oilseed Sunflower Cultivars
}

Roger W. Bullard

Paul P. Woronecki

Richard A. Dolbeer

J. Russell Mason

Follow this and additional works at: https://digitalcommons.unl.edu/icwdm_usdanwrc

Part of the Environmental Sciences Commons

Bullard, Roger W.; Woronecki, Paul P.; Dolbeer, Richard A.; and Russell Mason, J., "Biochemical and Morphological Characteristics in Maturing Achenes from Purple-Hulled and Oilseed Sunflower Cultivars" (1989). USDA National Wildlife Research Center - Staff Publications. 141.

https://digitalcommons.unl.edu/icwdm_usdanwrc/141

This Article is brought to you for free and open access by the U.S. Department of Agriculture: Animal and Plant Health Inspection Service at DigitalCommons@University of Nebraska - Lincoln. It has been accepted for inclusion in USDA National Wildlife Research Center - Staff Publications by an authorized administrator of DigitalCommons@University of Nebraska - Lincoln. 
microsome Mutagenicity Test. Mutat. Res. 1975, 31, 347-364.

Blair, C. A.; Shibamoto, T. Ames Mutagenicity Tests of Overheated Brewed Coffee. Food Chem. Toxic. 1984, 22, 971-975. Clarke, R. J. Coffee Manufacture. Proc. Biochem. 1967, 2, 15-19.

Friederich, U.; Hann, D.; Albertini, S.; Schlatter, Ch.; Wurgler, F. E. Mutagenicity Studies on Coffee. The Influence of Different Factors on the Mutagenic Activity in the Salmonella mammalian Microsome Assay. Mutat. Res. 1985, 156, 39-52.

Fujita, Y.; Wakabayashi, K.; Nagao, M.; Sugimura, T. Implication of Hydrogen Peroxide in the Mutagenicity of Coffee. Mutat. Res. 1985, 144, 227-230.

Hargraves, W. A.; Pariza, M. W. Purification and Mass Spectral Characterization of Bacterial Mutagens from Commercial Beef Extract. Cancer Res. 1983, 43, 1467-1472.

Hayatsu, H.; Oka, T.; Wakata, A.; Ohara, Y.; Hayatsu, T.; Kobayashi, H.; Arimoto, S. Adsorption of Mutagens to Cotton Bearing Covalently Bound Trisulfo-copper-phthalocyanine. Mutat. Res. 1983, 119, 233-238.

Kasai, H.; Yamaizumi, Z.; Wakabayashi, K.; Nagao, M.; Sugimura, T.; Yokoyama, S.; Miyazawa, T.; Spingarn, N. E.; Weisburger, J. H.; Nishimura, S. Potent Novel Mutagens Produced by Broiling Fish under Normal Conditions. Proc. Jpn. Acad., Ser. B 1980a, 56, 278-283.

Kasai, H.; Yamaizumi, Z.; Wakabayashi, K.; Nagao, M.; Sugimura, T.; Yokoyama, S.; Miyazawa, T.; Nishimura, S. Structure and Chemical Synthesis of Me-IQ, a Potent Mutagen Isoleted from Broiled Fish. Chem. Lett. 1980b, 1391-1394.

Kasai, H.; Kumeno, K.; Yamaizumi, Z.; Nishimura, S.; Nagao, M.; Fujita, Y.; Sugimura, T.; Nukaya, H.; Kosuge, T. Mutagenicity of Methylglyoxal in Coffee. Jpn. J. Cancer Res. (Gann) 1982 $73,681-683$.

Kato, T.; Kikugawa, K.; Hayatsu, H. Occurrence of the Mutagen 2-Amino-3,8-dimethylimidazo[4,5-f]quinoxaline (MeIQx) and 2-Amino-3,4,8-trimethylimidazo[4,5-f] quinoxaline $\left(4,8-\mathrm{Me}_{2} \mathrm{IQx}\right)$ in Some Japanese Smoked, Dried Fish Products. J. Agric. Food Chem. 1986, 34, 810-814.

Kikugawa, K.; Kato, T. Formation of Mutagens, 2-Amino-3,8dimethylimidazo[4,5-f]quinoxaline (MeIQx) and 2-Amino- 3,4,8-trimethylimidazo[4,5-f]quinoxaline (4,8-DiMeIQx), in Heated Fish Meats. Mutat. Res. 1987, 179, 5-14.

Kikugawa, K.; Kato, T.; Hayatsu, H. Screaning of Mutagenicity of Processed Foods by the Use of Blue Cotton. J. Food Hyg. Soc. Jpn. 1985, 26, 432-436.

Kikugawa, K.; Kato, T.; Hayatsu, H. The Presence of 2-Amino3,8-dimethylimidazo[4,5-f]quinoxaline in Smoked Dry Bonito (Katsuobushi). Jpn. J. Cancer Res. (Gann) 1986, 77, 99-102.

Nagao, M.; Takahashi, Y.; Yamanaka, H.; Sugimura, T. Mutagens in Coffee and Tea. Mutat. Res. 1979, 68, 101-106.

Sugimura, T. Carcinogenicity of Mutagenic Heterocyclic Amines Formed during the Cooking Process. Mutat. Res. 1985, 150, 33-41.

Sugimura, T.; Nagao, M. The Use of Mutagenicity to Evaluate Carcinogenic Hazards in Our Daily Lives. In Mutagenicity: New Horizons in Genetic Toxicology; Heddle, J. A., Ed.; Academic Press: New York, 1982; pp 73-88.

Sugimura, T.; Sato, S. Mutagens-carcinogens in Foods. Cancer Res. (Suppl.) 1983, 43, 2415-2421.

Yahagi, T.; Nagao, M.; Seino, Y.; Matsushima, T.; Sugimura, T.; Okada, M. Mutagenicities of N-Nitrosamines on Salmonella. Mutat. Res. 1977, 48, 121-136.

Yamaizumi, Z.; Kasai, H.; Nishimura, S.; Edmonds, C. G.; McCloskey, J. A. Stable Isotope Dilution Quantification of Mutagens in Cooked Foods by Combined Liquid Chromatography-thermospray Mass Spectrometry. Mutat. Res. 1986, 173, $1-7$.

Yamasaki, W.; Ames, B. N. Concentration of Mutagens from Urine by Adsorption with the Nonpolar Resin XAD-2: Cigarette Smokers Have Mutagenic Urine. Proc. Natl. Acad. Sci. U.S.A. 1977, 74, 3555-3559.

Yoshida, D.; Matsumoto, T.; Yoshimura, R.; Matsuzaki, T. Mutagenicity of Amino- $\alpha$-carbolines in Pyrolysis Products of Soybean Globulin. Biochem. Biophys. Res. Commun. 1978, $83,915-920$.

Received for review May 16, 1988. Accepted February 21, 1989.

\title{
Biochemical and Morphological Characteristics in Maturing Achenes from Purple-Hulled and Oilseed Sunflower Cultivars
}

\author{
Roger W. Bullard,* Paul P. Woronecki, Richard A. Dolbeer, and J. Russell Mason
}

\begin{abstract}
The blackbird feeding preference for sunflower oilseed variety Jacques Discovery (JD) over purple-hulled Neagra de Cluj $(\mathrm{NdC})$ has been attributed to anthocyanin. To test this hypothesis, we compared biochemical and morphological properties in the achene over the maturation period. Comparisons included total phenols, anthocyanin, tannin, fat/oil, protein, nonstructural sugars, and phytomelanin contents, as well as mass properties and moisture content. Only three differences were observed: (1) Hull mass was significantly higher for NdC than JD. (2) Anthocyanins were synthesized by NdC only. (3) JD was higher in oil content. Each of these factors may play a role in reduced preferences exhibited by birds for $\mathrm{NdC}$.
\end{abstract}

Bird-resistant traits in ripening agricultural crops usually involve a combination of morphological and biochemical

U.S. Department of Agriculture-Animal and Plant Health Inspection Service, Denver Wildlife Research Center, Bldg. 16, Denver Federal Center, Denver, Colorado 80225 (R.W.B.), U.S. Department of Agriculture-Animal and Plant Health Inspection Service, Denver Wildlife Research Center, Ohio Research Station, c/o Plum Brook Station, 6100 Columbus Avenue, Sandusky, Ohio 44870 (P.P.W., R.A.D.), and U.S. Department of AgricultureAnimal and Plant Health Inspection Service, Denver Wildlife Research Center, c/o Monell Chemical Senses Center, 3500 Market Street, Philadelphia, Pennsylvania 19104 (J.R.M.). characteristics (Bullard and York, 1984). In developing bird-tolerant cultivars the two modes of protection are usually pursued simultaneously, resulting in cultivars that contain traits of both. This has been a productive approach in sorghum (Voight, 1966) and corn (Dolbeer et al., 1982) and is the one being followed by plant geneticists working on bird-resistant sunflower varieties ( $F$ ox and Linz, 1983; Foley and Hanzel, 1986). Morphological features thought to increase resistance include concave heads, long bracts, heads that face the ground, head-to-stem distances exceeding $15 \mathrm{~cm}$, and seeds with tough fibrous hulls (Parfitt, 1984). Biochemical features thought to increase resistance include chlorogenic acid (Harada, 1977) and anthocyanins in purple-hulled varieties (Dolbeer et al., 1986; Fox and Linz, 1983; Mason et al., 1986). Chlo- 
rogenic acid has since been rejected (Fox and Parfitt, 1982).

Anthocyanin in purple-hulled varieties is entirely concentrated into a highly accessable thin layer in the pericarp hypodermal cells (Knowles, 1978) among hairs protruding from the surface. Thus, the chemical is readily accessable to removal through contact or by extraction. Anthocyanin pigments are $\mathrm{pH}$ sensitive: Below $\mathrm{pH} 3$ solutions display their most intense red coloration while in the range $\mathrm{pH}$ 4-5 they become almost colorless. Further increases in $\mathrm{pH}$ give rise to purples or blues similar to that observed in vivo in purple-hulled sunflower varieties (Jackman and Yada, 1987). Anthocyanins are particularly recognized among the phenolics for their instability, which makes it difficult to relate laboratory extractions and analyses with the natural state found in the plant source. The extraction of $\mathrm{NdC}$ hulls with water produces an extract that turns brown on standing, and the often-used $1 \% \mathrm{HCl}$ in methanol extraction medium will hydrolyze acylated anthocyanins at room temperature (Holm, E. T., 1987, personal communication).

In one series of laboratory taste preference tests of achenes from purple-hulled Neagra de Cluj $(\mathrm{NdC})$ and three other sunflower varieties on individually caged redwinged blackbirds (rwbb; Agelaius phoeniceus), there were some indications of anthocyanin avoidance (Mason et al., 1986). However, a companion series of aviary and field tests of feeding preference among heads from the standing crops (Dolbeer et al., 1986) indicated that initially birds avoided $\mathrm{NdC}$ but that the resistance "began to break down under severe feeding pressure when a convenient source of preferred sunflower seed was depleted".

When the anthocyanin question was pursued further, the present assessment of maturing achene characteristics was compared with feeding preference behavior (Mason et al., 1989) in field, outdoor aviary, and laboratory tests. The objectives were to measure several biochemical and morphological properties of $\mathrm{NdC}$ and Jacques Discovery (JD, a commercial oilseed variety) achenes at each of six maturational stages, to correlate these data with those from the behavioral tests at each stage, and to attempt to relate behavioral responses to differences in the biochemical and morphological properties.

\section{MATERIALS AND METHODS}

Sampling. Sunflower heads of synchronous maturity from JD and NdC varieties (planted 14 June 1986; Erie County, OH; Mason et al., 1989) were collected randomly throughout the field on six dates from 19 Aug to 29 Sept $1986(5,10,15,25,35$, and 45 days after bloom (DAB)). To minimize biochemical changes that could influence chemical analytical test data, each head was quick-frozen immediately after cutting by immersion in liquid nitrogen. Subsequently, in a cold room an achene sample for each test catergory was separated from debris, lyophilized, and held at $-5{ }^{\circ} \mathrm{C}$. For tests requiring dehulling, hulls were removed from the respective sample aliquot by hand with forceps. All grinding of whole achenes, meats, or hulls was to 20 mesh with a Wiley mill.

Achene, Meat, and Hull Weights: Moisture. Hulls were separated from the meats of three randomly selected 50 achene sample aliquots and weighed. Whole achene mass was determined on another set of three randomly selected sample aliquots. For moisture determinations, achene samples collected fresh were held in a $30^{\circ} \mathrm{C}$ drying room for 3 weeks.

Phytomelanin (Armored Layer) Detection. Six randomly selected achene sample aliquots from each sunflower sample were placed in a 3:1 saturated potassium dichromate-concentrated sulfuric acid solution and held for $30 \mathrm{~min}$ (Seiler et al., 1984). After each immersion, a black coating on the hull indicates the presence of an armored layer while an achene without the layer appears white.

Phenolic Compounds. For examination of total phenolics, 1-g sample aliquots of ground whole achenes were extracted with

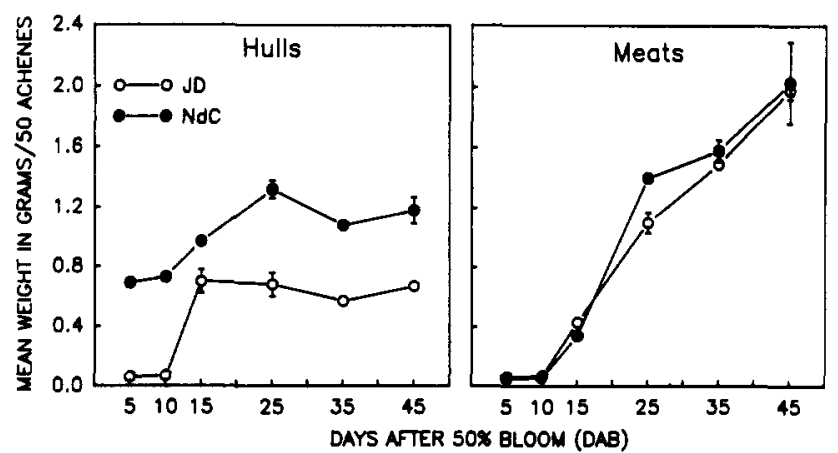

Figure 1. Mean weight ( $\mathrm{g}$ ) of hulls and meats from 50 achenes in each maturity class (i.e., $5,10,15,25,35$, and 45 DAB) in JD and $\mathrm{NdC}$.

$5 \mathrm{~mL}$ of methanol for $1 \mathrm{~h}$ on a platform shaker and centrifuged at $4500 \mathrm{rpm}$ for $10 \mathrm{~min}$. A $50-\mu \mathrm{L}$ sample of the supernatant was combined with $2 \mathrm{~mL}$ of water and $0.2 \mathrm{~mL}$ of Folin-Ciocalteau reagent (Sigma, St. Louis, MO). The solution was vortexed and allowed to stand for $1 \mathrm{~min}$. Next, $5 \mathrm{~mL}$ of $1 \mathrm{M}$ ethanolamine was added and the solution vortexed and timed for $10 \mathrm{~min}$ to determine $A_{750}$ of the phosphomolybdate blue color on a Beckman DK2A spectrophotometer. Catechin was used for the standard curve, and data are reported in terms of catechin equivalents.

Tannin analyses were conducted by determining the proteinbinding activity of methanol extracts from ground achenes in a bovine serum albumin solution, using quantities identical with specifications for analysis of sorghum grain (Bullard et al., 1981).

A new method was developed for determining anthocyanin concentrations in achene hulls. A 250 -mg ground hull sample aliquot was extracted with $10 \mathrm{~mL}$ of $0.5 \% \mathrm{HCl}$ in methanol by shaking for $15 \mathrm{~min}$ on a platform shaker, the mixture immediately centrifuged at $6500 \mathrm{rpm}$ for $10 \mathrm{~min}$, and the supernatant stored in a freezer until analysis. In $280-800-\mathrm{nm}$ spectra conducted on a Beckman DK2A recording spectrophotometer, the absorbance maximum for $\mathrm{NdC}$ anthocyanin was found to be at $528 \mathrm{~nm}$. Since cyanidins are reported to be one of the important structural components involved in anthocyanin formation in sunflowers (Holm, E. T., personal communication), and its absorption maximum was almost identical with that of $\mathrm{NdC}$ anthocyanin, cyanadin-Cl (K\&K Laboratories, Plainview, NY) served as the reference standard for quantative analysis purposes. Anthocyanin $A_{528}$ values were determined on all $\mathrm{NdC}$ and JD samples and are reported as cyanidin equivalents.

Total Nonstructural Carbohydrates (Sugars). Ground meats were analyzed by standard methods (Smith et al., 1964) for total nonstructural carbohydrates (TNC) by the Range Science Nutritional Analysis Laboratory, Colorado State University, Fort Collins, $\mathrm{CO}$. Briefly, ground meats were digested in $\mathrm{H}_{2} \mathrm{SO}_{4}$, and an iodometric technique was used to analyze the resulting extract.

Nitrogen and Protein. Ground meats were analyzed for nitrogen and protein content by the Range Science Nutritional Analysis Laboratory, Colorado State, University, Fort Collins, CO, using a standard micro-Kjeldahl method (Cole and Parks, 1946).

Lipids. Ground meats were analyzed for fat and oil content by Agricultural Consultants, Inc., Brighton, CO. Two-gram samples were extracted for $4 \mathrm{~h}$ on a Goldfisch fat/oil extractor, according to AOAC methods (1975).

Data Analyses. Each sample (i.e., achenes from either NdC or JD collected at one of the six sampling dates) was analyzed by each of the above methods for the respective value. Mean values, collapsed across $\mathrm{DAB}$, were computed for $\mathrm{NdC}$ and JD in each assessment. These means were then evaluated in a Wilcoxon signed rank two-tailed test with $P=0.05$ level of significance.

\section{RESULTS}

Achene, Meat, and Hull Weights. NdC had significantly higher achene and hull mean weight values than JD (Figure 1). There were no overall differences in meat weights or in moisture content between $\mathrm{NdC}$ and JD. Developmentally, biosynthesis of hull structures predominated until $10 \mathrm{DAB}$, with little change in achene mass. 
Table I. Biochemical Properties of Ripening Achenes from Neagra de Cluj (NdC) and Jacques Discovery (JD) Varieties

\begin{tabular}{|c|c|c|c|c|c|c|c|}
\hline \multirow[b]{2}{*}{ variety } & \multirow[b]{2}{*}{$\mathrm{DAB}^{a}$} & \multicolumn{3}{|c|}{ achene } & \multicolumn{2}{|c|}{ meat } & \multirow{2}{*}{$\begin{array}{c}\text { hull: } \\
\text { \% anthocyanin }\end{array}$} \\
\hline & & $\%$ moisture & $\%$ fat/oil & $\%$ phenolics & $\%$ protein & $\%$ sugars & \\
\hline JD & 5 & 77 & 5.0 & 0.0 & & & 0.00 \\
\hline JD & 10 & 81 & 4.8 & 0.13 & 17.89 & 38.65 & 0.04 \\
\hline JD & 15 & 74 & 14.1 & 0.17 & 22.45 & 17.71 & 0.11 \\
\hline JD & 25 & 58 & 40.1 & 0.10 & 21.82 & 3.37 & 0.04 \\
\hline JD & 35 & 48 & 49.8 & 0.12 & 18.11 & 1.55 & 0.06 \\
\hline JD & 45 & 22 & 48.7 & 0.63 & 20.35 & 3.91 & 0.13 \\
\hline $\mathrm{NdC}$ & 5 & 78 & 2.6 & 0.05 & & & 0.11 \\
\hline $\mathrm{NdC}$ & 10 & 82 & 3.2 & 0.11 & 17.81 & 36.75 & 0.11 \\
\hline $\mathrm{NdC}$ & 15 & 75 & 5.8 & 0.12 & 23.04 & 25.17 & 0.15 \\
\hline $\mathrm{NdC}$ & 25 & 57 & 27.0 & 0.15 & 31.12 & 2.53 & 1.75 \\
\hline $\mathrm{NdC}$ & 35 & 42 & 30.6 & 0.35 & 31.42 & 2.61 & 5.14 \\
\hline $\mathrm{NdC}$ & 45 & 21 & 33.3 & 0.46 & 30.07 & 4.58 & 5.73 \\
\hline
\end{tabular}

${ }^{a}$ Days after bloom.

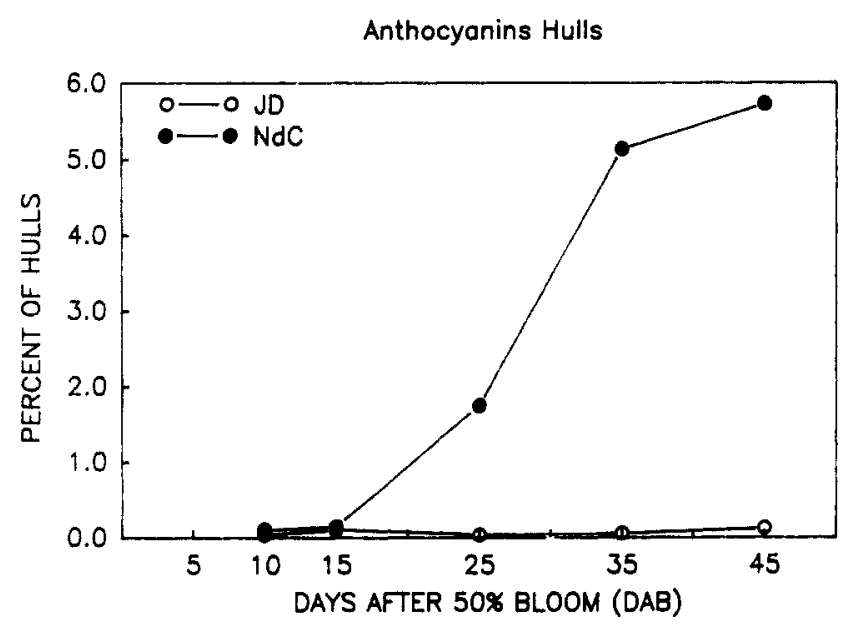

Figure 2. Percent of anthocyanin in hulls from JD and NdC for each maturity class (i.e., $5,10,15,25,35$, and $45 \mathrm{DAB}$ ).

By 15 DAB hull development had plateaued, and meat weights began to increase with a burst of development between 15 and $25 \mathrm{DAB}$ and then a slower, steadier growth until 45 DAB.

Phytomelanin Detection. There was no armored layer detected on the hulls of either variety.

Phenolic Compounds. Similar levels of total phenolics (Table I) were detected in both $\mathrm{NdC}$ and JD. Tannins were not detected in either variety, but obviously other compounds such as chlorogenic acid (Harada, 1977) were present.

Anthocyanin concentrations were significantly higher in NdC than JD. Table I and Figure 2 indicate that up to $0.13 \%$ of the anthocyanin values was attributed to trace quantities of other compounds detectable by the analytical method. Biosynthesis of anthocyanin began between 15 and $25 \mathrm{DAB}$ and accelerated over later sampling dates. By $45 \mathrm{DAB}$, anthocyanins comprised nearly $6 \%$ of $\mathrm{NdC}$ hull mass.

Total Nonstructural Carbohydrates. There were no differences in TNC for the two varieties. Table I suggests that sugars were a major component in the meats of both varieties until $15 \mathrm{DAB}$. However, little biosynthesis occurred subsequently, and at later sampling dates, sugars were a minor component of meat masses.

Protein. There were no overall differences between JD and $\mathrm{NdC}$ in nitrogen content or percent protein. However, the data do suggest greater protein values in $\mathrm{NdC}$ at 25 , 35 , and 45 DAB (Table I; Figure 3).

Lipids. Meats from JD samples were significantly higher in oil than meats from NdC samples. Examination of Table I and Figure 2 indicates that oil biosynthesis
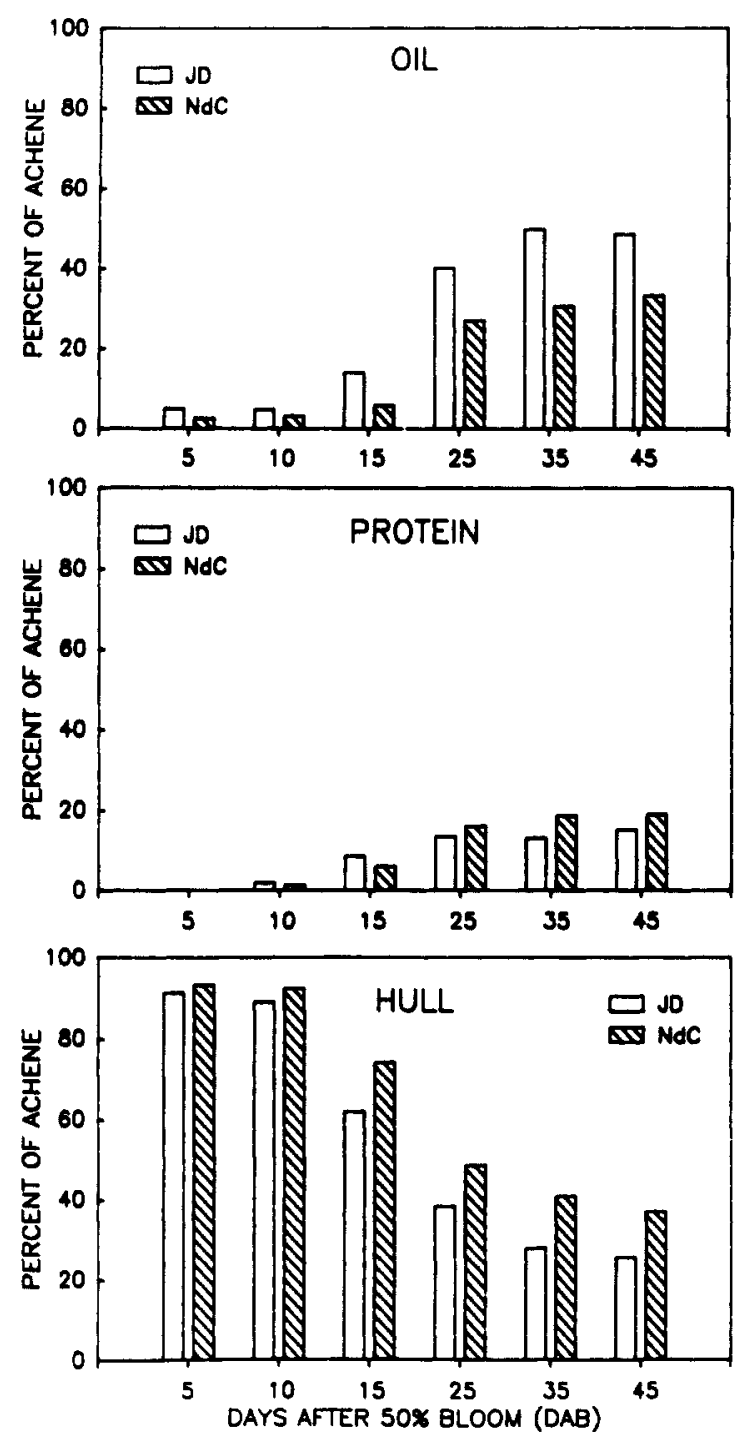

Figure 3. Percent of oil, protein, and hull in achenes from each maturity class (i.e., $5,10,15,25,35$, and $45 \mathrm{DAB}$ ) of JD and NdC.

began between 10 and $15 \mathrm{DAB}$, with the bulk of biosynthesis occurring between 15 and 25 DAB.

DISCUSSION AND MANAGEMENT IMPLICATIONS

$\mathrm{NdC}$ and JD appear to differ most in hull weight ( $\mathrm{NdC}$ is greater), anthocyanin concentration (NdC is higher), and oil concentration ( $\mathrm{NdC}$ is lower). Any one of these features may influence consumption by birds.

Regarding anthocyanin as a taste repellent to rwbb, the chronology of biosynthesis in this study raises some questions concerning the influence of anthocyanin con- 
centration on feeding behavior. JD was highly preferred at each test date in one-choice aviary tests (Mason et al., 1989), yet at $15 \mathrm{DAB}$ there are only $0.15 \%$ anthocyanin and $1.75 \%$ at $25 \mathrm{DAB}$ in $\mathrm{NdC}$ hulls. It was between 25 and $35 \mathrm{DAB}$ where the big increase (nearly 3 -fold) in anthocyanin synthesis occurred. The heaviest feeding for $\mathrm{NdC}$ in the no-choice test and for both varieties in the one-choice test occurred at 10 and 15 DAB. Our results coincide with an oilseed sunflower damage chronology study conducted between 1979 and 1982 by Cummings et al. (1989). In their studies (adjusted to our DAB scale), over $75 \%$ of the total bird damage occurred within the first $28 \mathrm{DAB}$, with the peak occurring between 16 and $25 \mathrm{DAB}$.

However, total hull anthocyanin on a dry-weight basis may be somewhat misleading. Factors other than quantity could influence chemoreception in rwbb. For example, moisture content in the hypodermis cellular structure could increase the release of anthocyanin into the moist mouth of a bird during the brief manipulation required for dehulling. We did not observe an appreciable drop in moisture content (Table I) of the samples until after 15 $\mathrm{DAB}$, and then it decreased as anthocyanin increased. This hypothesis is not consistent, however, with the results obtained in recent studies; two experiments involving visual examination of rwbb feeding behavior on immature $\mathrm{NdC}$ indicated that taste was not involved in rwbb avoidance (Mah, 1988).

Regarding oil content, some consider that birds prefer foods containing greater amounts of lipid (Besser, 1978). If rwbb seed consumption is related to oil content, the higher levells in JD (Table I; Figure 2), especially at 25, 35 , and $45 \mathrm{DAB}$, could influence the feeding behavior of rwbb in tests involving a feeding choice between the two. In a study similar to this one, Samanci (1987) compared bird damage to oilseed variety hybrid $894, \mathrm{NdC}$, and candidate morphological resistant hybrids BRS-1 and ND 80116-15-1 and concluded that "genotypes with higher kernel and oil contents suffer heavier damage".

Differences in achene and hull mass may also have influenced rwbb feeding patterns in our studies. The difference in hull mass was especially noticeable in the early stages (Table I; Figures 1 and 2). At 15 DAB hull formation was nearly complete, very little oil formation had taken place, and there were no significant differences in protein or sugars, yet JD was highly preferred in field and aviary studies (Mason et al., 1989). Thus, until 15 DAB hull mass is the best explanation we have of preference differences in this study. The pattern may have continued throughout the remaining test dates considering the differences in hull mass between the two varieties.

The optimal feeding theory predicts that birds should choose the food item maximizing the net energy intake (Pyke, 1984). If this applies to the feeding choices in our study and a thinner hull makes dehulling an easier task, birds would tend to favor JD as a food item. Oil is a rich source of energy and dehulling activity by birds consumes feeding energy, meaning birds would benefit by (1) expending less energy in dehulling JD (2) to reach a meat of higher energy value.

Across the industry, sunflower breeders generally recognize that hull mass and seed size are inversely correlated with oil content (Fick, 1978; Fox and Linz, 1983). Perhaps, this is the reason that confectionary varieties are less desirable than oilseed varieties (Besser, 1978; Fick, 1978; Fox and Linz, 1983). Lofgren (1978) published data of $45.8 \%$ and $28.2 \%$, respectively, for the average hull and oil content in four typical confectionary varieties while Dorell (1978), in the same book, gave values for five oilseed cultivars averaging 24.4 and $50.5 \%$, respectively. These data are very similar to ours for $\mathrm{NdC}$ and JD (Figure 2), indicating that $\mathrm{NdC}$ is more like a confectionary variety than an oilseed variety. Samanci (1987) went so far as to agronomically categorize it with two candidate morphological genotypes having thick hulls and low oil content.

Thus, evidence is mounting that factors other than anthocyanin could be involved in reduced preference for $\mathrm{NdC}$ when it is accompanied by the presence of an oilseed variety. Further studies are being planned to explore the importance of hull mass and oil content in rwbb feeding behavior and to conduct a specific taste repellent study on extracted sunflower anthocyanin.

\section{ACKNOWLEDGMENT}

We thank P. E. Harris, D. J. Cunninghan, and J. E. Davis for technical assistance. G. M. Linz, S. A. Shumake, and D. L. Otis provided value critiques of the manuscript.

\section{LITERATURE CITED}

AOAC. Official Methods of Analysis, 12th ed.; Association of Official Agricultural Chemists: 1975; Method No. 7.045.

Besser, J. F. Birds and Sunflower. In Sunflower Science and Technology (Agronomy 19); Carter, J. F., Ed.; American Society of Agronomy, Crop Science Society of America, and Soil Science Society of America, Inc.: Madison, WI, 1978.

Bullard, R. W.; York, J. O. Breeding for Bird Resistance in Sorghum and Maize. In Progress in Plant Breding; Russell, G. E., Ed.; Butterworths: England, 1984; Vol. 1.

Bullard, R. W.; York, J. O.; Kilburn, S. R. Polyphenolic Changes in Ripening Bird-Resistant Sorghums. J. Agric. Food Chem. 1981, 29, 973-981.

Cole, J. O.; Parks, C. R. Seimimicro-Kjeldahl Procedure for Control Laboratories. Ind. Eng. Chem. Anal. Ed.) 1946, 8, 61-64.

Cummings, J. L.; Guarino, J. L.; Knittle, C. E. Chronology of Black-bird Damage to Sunflowers. Wildl. Soc. Bull. 1989, in press.

Dolbeer, R. A.; Woronecki, P. P.; Stehn, R. A. Effect of Ear Characteristics on Resistance of Maize to Blackbird (Agelaius phoeniceus) damage in Ohio. Prot. Ecol. 1982, 4, 127-139.

Dolbeer, R. A.; Woronecki, P. P.; Stehn, R. A.; Fox, G. J.; Hanzel, J. J.; Linz, G. M. Field Trials of Sunflower Resistant to Bird Depredation. North Dakota Farm Res. 1986, 43, 21-24, 28.

Dorrell, D. G. Processing and Utilization of Oilseed Sunflower. In Sunflower Science Technology (Agronomy 19); Carter, J. F., Ed.; American Society of Agronomy, Crop Science Society of America, and Soil Science Society of America, Inc.: Madison, WI, 1978.

Fick, G. N. Breeding and Genetics. In Sunflower Science and Technology (Agronomy 19); Carter, J. F., Ed.; American Society of Agronomy, Crop Science of America, Soil Science Society of America, Inc.: Madison, WI, 1978.

Foley, R. J.; Hanzel, J. J. Inheritance of Morphological Traits Conferring Bird Resistance/Tolerance to Sunflower. Proceedings of the Sunflower Research Workshop; National Sunflower Association: Bismarck, ND, 1986.

Fox, G. J.; Parfitt, D. E. Genetic Sources of Resistance/Tolerance to Bird Predation of Sunflower. Agron. Abstr. 1982, 66-67.

Fox, G. J.; Linz, G. M. Evaluation of Red-Winged Blackbird Resistant Sunflower Germplasm. In Proceedings of the Ninth Bird Control Seminar; Jackson, W. B., Ed.; Bowling Green State University: Bowling Green, OH, 1983.

Harada, W. A Possible Deterrent to Bird Damage in Sunflower. In Proceedings of the Second Sunflower Forum; National Sunflower Association: Bismarck, ND, 1977.

Jackman, R. L.; Yada, R. Y. Anthocyanins as Food Colorants-A Review. J. Food Biochem. 1987, 11, 201-247.

Knowles, P. F. Morphology and Anatomy. In Sunflower Science and Technology (Agronomy 19); Carter, J. F., Ed.; American Society of Agronomy, Crop Science of America, Soil Science Society of America, Inc.: Madison, WI, 1978.

Lofgren, J. R. Sunflower for Confectionary Food, Birdfood, and Petfood. In Sunflower Science and Technology (Agronomy 19); Carter, J. F., Ed.; American Society of Agronomy, Crop 
Science of America, Soil Science Society of America, Inc.: Madison, WI, 1978.

Mah, J. Feeding Behavior of Redwinged Blackbirds on Sunflowers with Different Bird-Resistant Features. Ph.D. disseration, North Dakota State University at Fargo, 1988.

Mason, J. R.; Adams, M. A.; Dolbeer, R. A.; Stehn, R. A.; Woronecki, P. P.; Fox, G. J. Contribution of Seed Hull Characteristics to Resistance of Sunflower to Blackbird Damage. North Dakota Farm Res. 1986, 43, 16-20.

Mason, J. R.; Dolbeer, R. A.; Woronecki, P. P.; Adams, M. A.; Bullard, R. W. Maturational Changes in Sunflower Influence Consumption by Red-Winged Blackbirds. J. Wildl. Manage. 1989 , in press.

Parfitt, D. E. Relationship of Morphological Plant Characteristics of Sunflower to Bird Feeding. Can. J. Plant Sci. 1984, 64, $37-42$.
Pyke, G. H. Optimal Foraging Theory: A Critical Review. Annu. Rev. Ecol. Syst. 1984, 15, 523-575.

Samanci, B. The Relationship Between Date of Flowering and Degree of Bird Damage in Sunflower. M.S. Thesis, North Dakota State University at Fargo, 1987.

Seiler, G. J.; Stafford, R. E.; Rogers, C. E. Prevalence of Phytomelanin in Pericap of Sunflower Parental Lines and Wild Species. Crop Sci. 1984, 24, 1202-1204.

Smith, D. C.; Paulsen, G. N.; Raguse, C. A. Extraction of Total Available Carbohydrates from Grass and Legumes Tissue. Plant Physiol. 1964, 39, 960-962.

Voight, R. L. Bird-Tolerent Sorghums Boost Take-Home Yields. Prog. Agric. Ariz. 1966, 18, 30-32.

Received for review September 26, 1988. Accepted December 28, 1988.

\title{
Nonenzymic Autoxidative Phenolic Browning Reactions in a Caffeic Acid Model System
}

\author{
Johannes J. L. Cilliers ${ }^{1}$ and Vernon L. Singleton*
}

\begin{abstract}
Nonenzymic oxidation of caffeic acid was studied at $\mathrm{pH} 4.0-8.0$, at various concentrations $(1-10 \mathrm{mM})$ and at temperatures 5,20 , and $35^{\circ} \mathrm{C}$. The products of caffeic acid oxidation were investigated by high-performance liquid chromatography (HPLC) with diode array detection. The proportion of different oxidation products formed from the caffeic acid was affected by the conditions, but the major products are formed in each case and give a constant chromatographic profile under a given set of conditions. Later products appeared to derive by further reactions. The rate of the reaction is increased by increasing $\mathrm{pH}\left(164 \times 10^{-5} \mathrm{~h}^{-1}\right.$ at $\mathrm{pH} 4.0$ and $6020 \times 10^{-5} \mathrm{~h}^{-1}$ at $\mathrm{pH} 8.0$; both at $\left.35^{\circ} \mathrm{C}\right)$ and temperature $(\mathrm{pH} 8.0$ : $5^{\circ} \mathrm{C}, 764 \times 10^{-5} \mathrm{~h}^{-1} ; 35^{\circ} \mathrm{C}, 6020 \times 10^{-5} \mathrm{~h}^{-1}$. pH $\left.5.0: 5^{\circ} \mathrm{C}, 50 \times 10^{-5} \mathrm{~h}^{-1} ; 35^{\circ} \mathrm{C}, 825 \times 10^{-5} \mathrm{~h}^{-1}\right)$. The Arrhenius activation energy is $49.0 \pm 6.4 \mathrm{~kJ} \mathrm{~mol}^{-1}$ at pH 8.0 for caffeic acid oxidation. The intensity of brown produced at $35^{\circ} \mathrm{C}$ in $168 \mathrm{~h}$ was highest at $\mathrm{pH} 6$, followed by $\mathrm{pH} 7$ and then $\mathrm{pH} 8$. Brown $(420-\mathrm{nm})$ generation correlated well $(P \leq 0.001)$ with caffeic acid consumption at all pH's and temperatures. Some of the oxidation products were formed at equal maximum concentrations independent of the $\mathrm{pH}$ but at rates that were highest at high $\mathrm{pH}$. Others were dependent on $\mathrm{pH}$, and the highest concentrations and rates were found at high $\mathrm{pH}$. The controlling factor in the rate of autoxidation is indicated to be phenolate anion concentrations.
\end{abstract}

Polyphenols are widely distributed in the plant kingdom and are therefore present in all plant-derived food systems and most diets (Deshpande et al., 1984; Singleton, 1981). When fruits or vegetables are damaged by bruising or cutting, polyphenols are very much involved in enzymic browning reactions (Ozo and Caygill, 1986). Hydroxycinnamates such as chlorogenic and caftaric acids as well as flavonoids such as catechin serve as the principal substrates for the phenolase complex responsible for these reactions. However, processed foods with the phenolase destroyed are also susceptible to nonenzymic browning due to autoxidation reactions (Schusler et al., 1985; Singleton, 1987). These nonenzymic reactions have been much less studied, and phenolic browning has tended to be incorrectly equated only with enzymic oxidation.

Initial oxidation of compounds like caffeic acid results in formation of its quinone (Demmin et al., 1981; Fisher and Henderson, 1985). Once the quinone is formed, its

Department of Viticulture and Enology, University of California, Davis, California 95616.

${ }^{1}$ Present address: Division for Food Science and Technology, Council for Scientific and Industrial Research, P.O. Box 339, Pretoria, 0001, RSA. strong electrophilic nature makes it very susceptible to nucleophilic attack (Cabanes et al., 1987; Macomber, 1982). After the quinones are formed, the rest of the reaction is the same whether the quinone was produced enzymically or chemically. Therefore, the study of chemical oxidation products is universally applicable to many different types of food products. o-Quinones formed may react further with amino acids (Wang et al., 1985) or proteins (Kalyanaraman et al., 1987) or polymerize (Takizawa et al., 1985; White and Que, 1985). Other nutrients may also be directly or indirectly affected via oxidation coupled to that of phenols (Igarashi and Yasui, 1985; Rigo et al., 1983; Scully and Hoigne, 1987; Suzuki and Itoh, 1986; Wildenradt and Singleton, 1974). Food processing that includes alkaline treatment leads to rapid phenol oxidation tying up amino acids and protein nitrogens and thus resulting in decreased nutritional value (Hurrel et al., 1982).

The same reaction takes place at an appreciable rate under acid conditions especially if metal catalysts are present (Hocking and Intihar, 1986; Speier, 1986). Chemical oxidations can even mimic enzymic reactions (Pandell, 1976, 1983). Trace elements naturally present or acquired during processing or from storage containers can catalyze these undesirable changes (in color, flavor, odor; consistency, and solubility) in the food product and 